Article

\title{
Accelerated Electro-Fermentation of Acetoin in Escherichia coli by Identifying Physiological Limitations of the Electron Transfer Kinetics and the Central Metabolism
}

\author{
Sebastian Beblawy ${ }^{1, \dagger}$, Laura-Alina Philipp ${ }^{1}$ and Johannes Gescher ${ }^{1,2, *}$ \\ 1 Department of Applied Biology, Institute for Applied Biosciences, Karlsruhe Institute of Technology, \\ Fritz-Haber-Weg 2, 76131 Karlsruhe, Germany; sebastian.beblawy@uni-tuebingen.de (S.B.); \\ laura-alina.philipp@kit.edu (L.-A.P.) \\ 2 Institute for Biological Interfaces, Karlsruhe Institute of Technology (KIT), Hermann-von-Helmholtz-Platz 1, \\ 76344 Eggenstein-Leopoldshafen, Germany \\ * Correspondence: johannes.gescher@kit.edu \\ † Current affiliation: Environmental Biotechnology, Centre for Applied Geosciences, University of Tübingen, \\ Schnarrenbergstr. 94-96, 72074 Tübingen, Germany.
}

Received: 25 September 2020; Accepted: 21 November 2020; Published: 23 November 2020

\begin{abstract}
Anode-assisted fermentations offer the benefit of an anoxic fermentation routine that can be applied to produce end-products with an oxidation state independent from the substrate. The whole cell biocatalyst transfers the surplus of electrons to an electrode that can be used as a non-depletable electron acceptor. So far, anode-assisted fermentations were shown to provide high carbon efficiencies but low space-time yields. This study aimed at increasing space-time yields of an Escherichia coli-based anode-assisted fermentation of glucose to acetoin. The experiments build on an obligate respiratory strain, that was advanced using selective adaptation and targeted strain development. Several transfers under respiratory conditions led to point mutations in the $\mathrm{pfl}$, ace $\mathrm{F}$ and $r p o C$ gene. These mutations increased anoxic growth by three-fold. Furthermore, overexpression of genes encoding a synthetic electron transport chain to methylene blue increased the electron transfer rate by 2.45 -fold. Overall, these measures and a medium optimization increased the space-time yield in an electrode-assisted fermentation by 3.6 -fold.
\end{abstract}

Keywords: electro-fermentation; acetoin; methylene blue; bulk chemicals; metabolic engineering; Escherichia coli

\section{Introduction}

Sustainable bioproduction will be the key to reaching the goal of a socio-economic transition into a bioeconomy. A low energy gain for the organisms and consequently a high catabolic production rate accompanied by low anabolic substrate conversion is favorable for fermentation-based biotechnological processes. This can be achieved under anoxic conditions. However, anoxic fermentations for instance the conversion of glucose to lactic acid or ethanol and carbon dioxide come with the boundary condition that the products must have the same oxidation state as the substrate. A more oxidized end-product demands the addition of an electron acceptor as oxygen. An elegant trade-off between both strategies was presented by Causey and colleagues. In this study, they disconnected oxygen reduction from energy generation by deleting parts of the membrane-bound ATPase $(\triangle a t p F H)[1]$. Although this concept solves the problem of an increasing biomass production rate, it cannot prevent the dissipation of a not negligible amount of energy in the form of heat. 
A possible further solution could be to couple a respiratory process with an infinitely available electron acceptor in an electrode-assisted fermentation [2-4]. Here, a solid-state anode of a bioelectrochemical system is the electron acceptor for the microorganisms. This electron acceptor can be poised to a defined potential which will also determine the kinetics of the fermentation process to a certain extent [5]. Moreover, the lower the potential at which the electrons are transferred to the anode the more energy they carry. This energy can for instance be used via the concept of a microbial electrolysis cell in which the electrons are used to produce hydrogen on the cathode side. Using a limited amount of further energy (cell voltages typically between $0.6 \mathrm{~V}$ and $0.9 \mathrm{~V}$ ), which is roughly $50 \%$ compared to conventional water electrolyzers (typically operating at 1.6 to $1.8 \mathrm{~V}$ ), the microbially produced current can be used on the cathode side for the production of hydrogen [6,7]. Moreover, an electrode-assisted fermentation can be conducted in a biofilm reactor which offers the benefit of continuous production processes using a natural retentostat, which makes it easy to separate the end-product from the substrate and the biocatalyst [8].

The direct respiratory interaction of microbes with anodes is restricted to a certain physiological class of microorganisms. These microbes contain an extended respiratory chain that consists usually out of $c$-type cytochrome proteins. One of the best-understood model organisms for anode respiration is Shewanella oneidensis, a $\gamma$-proteobacterium. S. oneidensis uses a tetraheme $c$-type cytochrome called CymA to transfer electrons from the menaquinone pool into the periplasm [9]. The two electron shuttling proteins Stc and FccA transfer the electrons through the periplasm and onto a trimeric complex in the outer membrane that consists of one $c$-type cytochrome on the periplasmic site and the cell surface, respectively, which are connected by a $\beta$-barrel protein $[10,11]$. The two outer membrane decaheme cytochromes MtrC and OmcA are the terminal reductases of the organism and possibly form a loosely attached complex [12-14].

A disadvantage of $S$. oneidensis is, that the organism has a rather restricted spectrum of carbon sources it can use under anoxic conditions and that it forms only thin biofilms on electrode surfaces. Therefore, several research groups tried to develop processes using different biocatalysts. One of these organisms is Pseudomonas putida that could be coupled to an anode as the electron acceptor for the production of 2-ketogluconate from glucose [15,16]. Electron transfer to the anode was possible by using different electron shuttles which were characterized by redox potentials above $0.207 \mathrm{~V}$ against a standard hydrogen electrode. With a similar strategy, Corynebacterium glutamicum was applied in an anode-assisted fermentation of lysine using ferricyanide as a redox mediator [17]. Another strategy to connect biocatalysts with an anode as the electron acceptor is the transplantation of an extracellular electron transport chain into a recipient biocatalyst strain, to enable either direct electron transfer or accelerate electron transfer using electron shuttles [18-21]. Förster et al. [22] developed an acetoin producing E. coli strain by deleting crucial genes of the mixed acid fermentation pathway ( $\operatorname{adh} E, \operatorname{ldh} A$, frdA-D and ack-pta) and expressing the acetolactate synthase (alsS) and acetolactate decarboxylase $($ alsD) of Bacillus subtilis (Figure 1). In this process a fermentation deficiency was achieved, rendering the metabolism under anoxic conditions dependent on respiratory electron acceptors such as nitrate or DMSO. Furthermore, they inserted the necessary elements of the electron transport chain of S. oneidensis to transfer electrons into the periplasm. Electron transfer to the anode was achieved by the aid of the membrane-permeable electron shuttle methylene blue that can be reduced by the cytochromes in the periplasm and reoxidized by interaction with the anode. Still, the deletion of key genes for fermentation pathways alone resulted in a pronounced decrease in the growth rate with several anoxic electron acceptors. Nevertheless, it was possible to achieve with this strain an electrode-assisted acetoin production process, that was characterized by very high carbon efficiencies but unfortunately low space-time-yields.

This study reports on several measures that were taken to increase the fitness of the strain under anoxic conditions and to increase the methylene blue reduction rates. We discovered-using adaptation experiments and resequencing of the resulting strain-mutations that increased the fitness of the strain under anoxic respiratory conditions. The genes identified in this experiment hint towards an 
anabolically constraint metabolism. Moreover, overexpressing key-genes for the electron transfer process we increased the methylene blue reduction rate of the organisms. In bioelectrochemical experiments, we demonstrate the success of the approach by increased production rates.

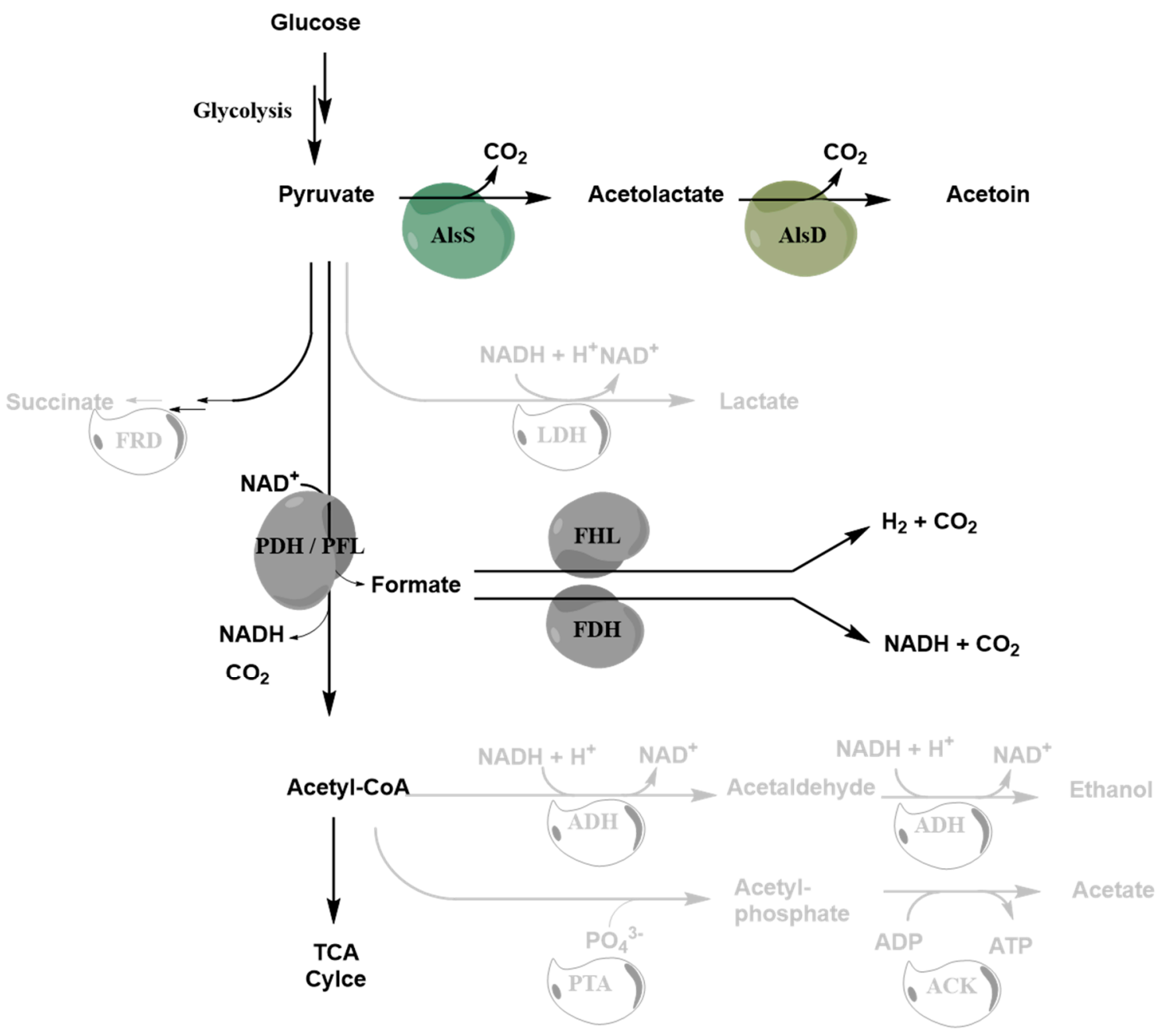

Figure 1. Overview of the modifications introduced by Förster et al. (2017) to the central metabolism of E. coli to facilitate the respiration dependent conversion of Glucose to Acetoin (JG991) [22]. Green shapes represent the heterologously expressed enzymes AlsS and AlsD, grey shapes are native enzymes of E. coli and hollow shapes and faded reactions indicate pathways that are blocked by gene deletions.

\section{Materials and Methods}

\subsection{Vector and Strain Construction}

The copy number of the cymA and stc gene in the E. coli strain JG1397 (Table 1) was increased by cloning the two genes behind the alsSD genes in the pMAL plasmid derived from Förster et al. [22] (Table 2). The cymA and stc genes were first codon-optimized for use in E. coli and amplified using Primer 1 and 2 (Table 3, Appendix A Sequence A4 and A5). Amplification also led to the elongation of the PCR fragment by homologous regions to the PMAL_alsSD plasmid. After cleaving this plasmid with SalI (New England Biolabs) the PCR fragment was inserted via isothermal DNA assembly [23]. The resulting plasmid was sequenced and transformed into JG1352 together with pEC86. 
Table 1. Strains used in this study.

\begin{tabular}{|c|c|c|c|}
\hline No. & Based on & Relevant Genotype & Reference \\
\hline JG22 & $\begin{array}{c}\text { E. coli } \\
\text { DH5 } \alpha \text { Z1 }\end{array}$ & $\begin{array}{l}\text { aciq, PN25-tetR, SpR, } \\
\text { deoR, supE44, } \triangle \text { (lacZYA } \\
\text { argFV169), Phis0 } \\
\text { lacZ } \Delta M 15\end{array}$ & [24] \\
\hline JG1054 & JG22 & pMAL alsSD & this study \\
\hline JG991 & JG22 & $\begin{array}{c}\Delta(\text { napC-F }), \Delta \text { frdA-D::(Ptet cymA mtrA, mtrB), } \\
\Delta \text { galK, } \Delta a d h E, \text { idh }:: P A r a \text { stc, } \triangle l d h A:: c s c R A K B, \\
\Delta p t a \text { ackA::galK } \\
\text { pMAL alsSD } \\
\text { pEC86 }\end{array}$ & [22] \\
\hline JG1295 & JG991 & $p f l^{-}$, aceF $F^{*}, r p o C^{-}$ & this study \\
\hline JG1352 & JG1295 & 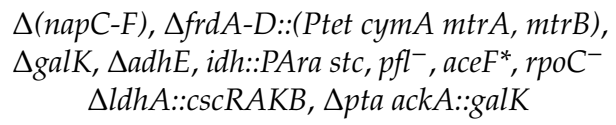 & this study \\
\hline JG1397 & JG1352 & $\begin{array}{c}\text { pMAL alsSD_cymA_stc } \\
\text { pEC } 86\end{array}$ & this study \\
\hline
\end{tabular}

Table 2. Vectors used in this study.

\begin{tabular}{ccc}
\hline Name & Relevant Genotype & Reference \\
\hline pMAL alsSD & bla, $\mathrm{P}_{\text {Tac }}$ alsSD & {$[22]$} \\
pMALalsSD_cymA_stc & bla, $\mathrm{P}_{\text {Tac }}$ alsSD, cymA, stc & this study \\
pEC86 & cat, $P_{\text {Tet }}$ ccmABCDEFGH & {$[25]$} \\
\hline
\end{tabular}

Table 3. Oligonucleotides used in this study.

\begin{tabular}{cc}
\hline No. & sequence \\
\hline 1 & CCCTTTTAGCAGGGCTTTCTGGAAGGAGATATACATACCATGAACTG \\
2 & AAACGACGGCCAGTGCCAAGCTTGCCTGCAGGTTATTTTTTCAGAACAGATGCGC \\
\hline
\end{tabular}

\subsection{Cell Cultivation}

Standard cultivation of $E$. coli was conducted at $37^{\circ} \mathrm{C}$ and $150 \mathrm{rpm}$ in LB medium ( $1 \%$ w/v yeast extract, $0.5 \% w / v \mathrm{NaCl}, 0.5 \% w / v$ peptone) supplemented with antibiotics for plasmid maintenance if necessary. Growth experiments were conducted in phosphate-buffered medium $(137 \mathrm{mmol} / \mathrm{L}$ $\mathrm{NaCl}, 2.7 \mathrm{mmol} / \mathrm{L} \mathrm{KCl}, 10 \mathrm{mmol} / \mathrm{L} \mathrm{Na} 2 \mathrm{HPO}_{4}, 1.76 \mathrm{mmol} / \mathrm{L} \mathrm{KH}_{2} \mathrm{PO}_{4}, 9 \mathrm{mmol} / \mathrm{L}\left(\mathrm{NH}_{4}\right)_{2} \mathrm{SO}_{4}, 1 \mathrm{mmol} / \mathrm{L}$ $\mathrm{MgSO}_{4}, 0.1 \mathrm{mmol} / \mathrm{L} \mathrm{CaCl}_{2}, 10 \mathrm{~mL} / \mathrm{L}$ trace element solution $\left(100 \times: 0.27 \mathrm{mmol} / \mathrm{L} \mathrm{CoCl}_{2}, 0.02 \mathrm{mmol} / \mathrm{L}\right.$ $\mathrm{CuSO}_{4}, 5.66 \mathrm{mmol} / \mathrm{L} \mathrm{H}_{3} \mathrm{BO}_{3}, 0.24 \mathrm{mmol} / \mathrm{L} \mathrm{FeCl}_{2}, 6.72 \mathrm{mmol} / \mathrm{L} \mathrm{Na}_{2}-\mathrm{EDTA}, 0.13 \mathrm{mmol} / \mathrm{L} \mathrm{MnSO}{ }_{4}$, $0.22 \mathrm{mmol} / \mathrm{L} \mathrm{Na}_{2} \mathrm{MoO}_{4}, 0.13 \mathrm{mmol} / \mathrm{L} \mathrm{Na}{ }_{2} \mathrm{SeO}_{4}, 1 \mathrm{mmol} / \mathrm{L} \mathrm{NaCl}, 0.5 \mathrm{mmol} / \mathrm{L} \mathrm{NiCl}, 0.16 \mathrm{mmol} / \mathrm{L}$ $\left.\mathrm{ZnSO}_{4}\right), 1 \mathrm{~g} / \mathrm{L}$ casein hydrolysate or yeast extract, $14.8 \mu \mathrm{mol} / \mathrm{L}$ thiamine, $20 \mathrm{mmol} / \mathrm{L}$ glucose) if not stated otherwise. Anoxic growth experiments were conducted in sealed bottles with $40 \mathrm{mmol} / \mathrm{L}$ $\mathrm{NO}_{3}{ }^{-}$or DMSO added to the medium. The medium was boiled before use and sparged with $\mathrm{N}_{2}$ gas. The initial $\mathrm{OD}_{600}$ for all growth experiments was 0.05 . If necessary, kanamycin $(10 \mu \mathrm{g} / \mathrm{mL})$, ampicillin $(100 \mu \mathrm{g} / \mathrm{mL})$, and chloramphenicol $(30 \mu \mathrm{g} / \mathrm{mL})$ were added to the medium. pMAL_alsSD or PMAL_alsSD_cymA_stc were induced using $50 \mu \mathrm{mol} / \mathrm{L}$ IPTG. For the induction of the $c y m A-m t r A$ locus and the stc locus, the culture was supplemented with $0.43 \mu \mathrm{mol} / \mathrm{L}$ anhydrotetracycline and 1 $\mathrm{mmol} / \mathrm{L}$ arabinose. Cell density was monitored photometrically using a SPECTRONIC Genesys 20 spectrophotometer (Thermo Fisher Scientific, Waltham, MA, USA) or an Ultrospec 10 Cell Density Meter (BioChrom, Holliston, MA, USA). 


\subsection{Adaptive Laboratory Evolution (ALE)}

ALE selection for an accelerated anaerobic metabolism with DMSO was performed in Hungate tubes containing $10 \mathrm{~mL}$ MOPS-buffered medium $(137 \mathrm{mmol} / \mathrm{L} \mathrm{NaCl}, 2.7 \mathrm{mmol} / \mathrm{L} \mathrm{KCl}, 15 \mathrm{mmol} / \mathrm{L}$ MOPS, $9 \mathrm{mmol} / \mathrm{L}\left(\mathrm{NH}_{4}\right)_{2} \mathrm{SO}_{4}, 1 \mathrm{mmol} / \mathrm{L} \mathrm{MgSO}_{4}, 0.1 \mathrm{mmol} / \mathrm{L} \mathrm{CaCl}_{2}, 10 \mathrm{~mL} / \mathrm{L}$ trace element solution, $1 \mathrm{~g} / \mathrm{L}$ casein hydrolysate or yeast extract). The medium was supplemented with $20 \mathrm{mmol} / \mathrm{L}$ Glucose, $40 \mathrm{mmol} / \mathrm{L}$ DMSO, $100 \mu \mathrm{mol} / \mathrm{L}$ methylene blue, and $14.8 \mu \mathrm{mol} / \mathrm{L}$ thiamine. The tubes were then inoculated with JG991 to an initial $\mathrm{OD}_{600}=0.05$. These cultures were incubated at $30^{\circ} \mathrm{C}$ and transferred into new tubes when the suspension became visibly turbid $\left(\mathrm{OD}_{600} \approx 0.3\right)$. For this purpose, the optical density was determined in all approaches at the beginning and end of each transfer and the number of generations was calculated ( $n=\log _{2} N-\log _{2} N_{0}, n=$ number of generations, $N=$ cell number). The next set of culture tubes was then inoculated with $1 \mathrm{~mL}$ culture of the tube with the highest number of cell divisions.

\subsection{Methylene Blue Reduction Assay}

The methylene blue reduction rate was determined in an anoxic cell suspension assay $\left(\mathrm{OD}_{600}=6\right)$ conducted in an anoxic chamber (Coy Laboratory Products, Grass Lake, MI, USA) with an $\mathrm{N}_{2} / \mathrm{H}_{2}$ atmosphere (98\%/2\%). Cells were pre-grown under anoxic conditions in M9 medium $(9.2 \mathrm{mmol} / \mathrm{L} \mathrm{NaCl}$, $21.2 \mathrm{mmol} / \mathrm{L} \mathrm{KH}_{2} \mathrm{PO}_{4}, 18.7 \mathrm{mmol} / \mathrm{L} \mathrm{NH}_{4} \mathrm{Cl}, 47.8 \mathrm{mmol} / \mathrm{L} \mathrm{Na}_{4} \mathrm{HPO}_{4}, 9 \mathrm{mmol} / \mathrm{L}, \mathrm{MgSO}_{4}, 0.1 \mathrm{mmol} / \mathrm{L}$ $\mathrm{CaCl}_{2}, 10 \mathrm{~mL} / \mathrm{L}$ trace element solution (100×: $0.27 \mathrm{mmol} / \mathrm{L} \mathrm{CoCl}_{2}, 0.02 \mathrm{mmol} / \mathrm{L} \mathrm{CuSO}_{4}, 5.66 \mathrm{mmol} / \mathrm{L}$ $\mathrm{H}_{3} \mathrm{BO}_{3}, 0.24 \mathrm{mmol} / \mathrm{L} \mathrm{FeCl}_{2}, 6.72 \mathrm{mmol} / \mathrm{L} \mathrm{Na}_{2}$-EDTA, $0.13 \mathrm{mmol} / \mathrm{L} \mathrm{MnSO}_{4}, 0.22 \mathrm{mmol} / \mathrm{L} \mathrm{Na}_{2} \mathrm{MoO}_{4}$, $\left.0.13 \mathrm{mmol} / \mathrm{L} \mathrm{Na}_{2} \mathrm{SeO}_{4}, 1 \mathrm{mmol} / \mathrm{L} \mathrm{NaCl}, 0.5 \mathrm{mmol} / \mathrm{L} \mathrm{NiCl}, 0.16 \mathrm{mmol} / \mathrm{L} \mathrm{ZnSO} 4\right), 1 \mathrm{~g} / \mathrm{L}$ casein hydrolysate, $14.8 \mu \mathrm{mol} / \mathrm{L}$ thiamine) with $50 \mathrm{mmol} / \mathrm{L}$ DMSO as sole electron acceptor and $0.5 \% w / v$ glycerol as carbon source. Antibiotics and, if necessary, IPTG, AHT, and arabinose were added as described above. The expression of the heterologous genes was induced at an $\mathrm{OD}_{600}$ of 0.3 . Cells were harvested and washed twice before the start of the assay. Cells were then diluted in $50 \mu \mathrm{L}$ media without an electron acceptor into a microtiter plate to an $\mathrm{OD}_{600}$ of 12 . The suspension was incubated for 30 min to remove any residual oxygen. To start the reduction assay, $50 \mu \mathrm{L}$ methylene blue with a concentration of $546 \mu \mathrm{mol} / \mathrm{L}$ were added simultaneously to each well with a dispenser tool (Infinite $200 \mathrm{PRO}$, Tecan, Männedorf, Switzerland). Absorption was measured at $620 \mathrm{~nm}$ using the Infinite 200 PRO spectrometer (Tecan, Männedorf, Switzerland). The assay was typically completed within $180 \mathrm{~s}$.

\subsection{Preparation of Nucleic Acids}

The preparation of plasmids and chromosomal DNA was carried out using $2 \mathrm{~mL}$ of an aerobic culture in LB medium. The plasmids were isolated using the Wizard Plus Miniprep DNA Purification System (Promega, Madison, WI, USA). The Wizard Genomic DNA Purification Kit (Promega, Madison, WI, USA) was used to isolate chromosomal DNA. Deviating from the protocol, the isolated DNA was rehydrated in the last step in $75 \mu \mathrm{L}$ Tris/ $\mathrm{HCl}$ buffer $(15 \mathrm{mmol} / \mathrm{L})$. Nucleic acids were quantified using a NanoDrop 2000 spectrophotometer (Thermo Fisher Scientific, Waltham, MA, USA). Chromosomal DNA was further quantified using the QBit dsDNA BR Assay Kit (Thermo Fisher Scientific, Waltham, MA, USA).

\subsection{Sequencing}

Plasmid DNA was sequenced using the Mix2SeqKit (Eurofins Genomics, Ebersberg, Germany). The genomes of JG1295 and JG991 were resequenced using an Illumina MiSeq with v2 chemistry (Illumina, San Diego, CA, USA) with $2 \times 250 \mathrm{bp}$ reads for the variant analysis. The library was created using the NEBNext ${ }^{\circledR}$ Ultra $^{\mathrm{TM}}$ II FS DNA kit. Illumina sequencing was carried out by IMGM Laboratories $\mathrm{GmbH}$ (Martinsried, Germany). 


\subsection{Bioinformatic Analysis}

The analysis of sequencing data was conducted using the CLC Genomics Workbench 11 (Qiagen, Venlo, The Netherlands). The workflow for NGS data contained: merging forward and reverse reads, a quality trim $(p=0.05)$, and mapping reads to the reference genome. The consensus sequence of the reference genome resequencing has been extracted by majority vote. This consensus sequence has been used as the reference for a variant analysis of the strain obtained from the ALE experiment. Variants with a fidelity $>90 \%$ and a coverage of $20 \times$ were regarded as significant.

\subsection{Electro-Fermentation}

In brief, the bioelectrochemical system had a volume of $23 \mathrm{~mL}$. The working electrode was a graphite felt $\left(40 \mathrm{~cm}^{2}\right.$ surface, GFD 2.5, Sigracell, Germany), and the counter electrode a platinum mesh $\left(1.25 \mathrm{~cm}^{2}\right.$, chemPUR, Karlsruhe, Germany). An Ag/AgCl electrode (Xylem group, Germany) was used as a reference. The anode potential was poised to $0 \mathrm{mV}$ against $\mathrm{Ag} / \mathrm{AgCl}$. The detailed procedure including schematics of the reactor system can be found in Förster et al. [22]. Differing from that, a MOPS buffered medium was used supplemented with $0.1 \%$ yeast extract and 10 or $50 \mathrm{mmol} / \mathrm{L}$ Glucose. The $\mathrm{pH}$ value of 7.2 was maintained using a pH-controller (Hach Lange, Düsseldorf, Germany) feeding a $0.5 \mathrm{mmol} / \mathrm{L} \mathrm{NaOH}$ solution. The electrical current was recorded for $8 \mathrm{~h}$. Of note, the doubling time of the organisms. under these conditions will be at least $20 \mathrm{~h}$ (Figure 2).
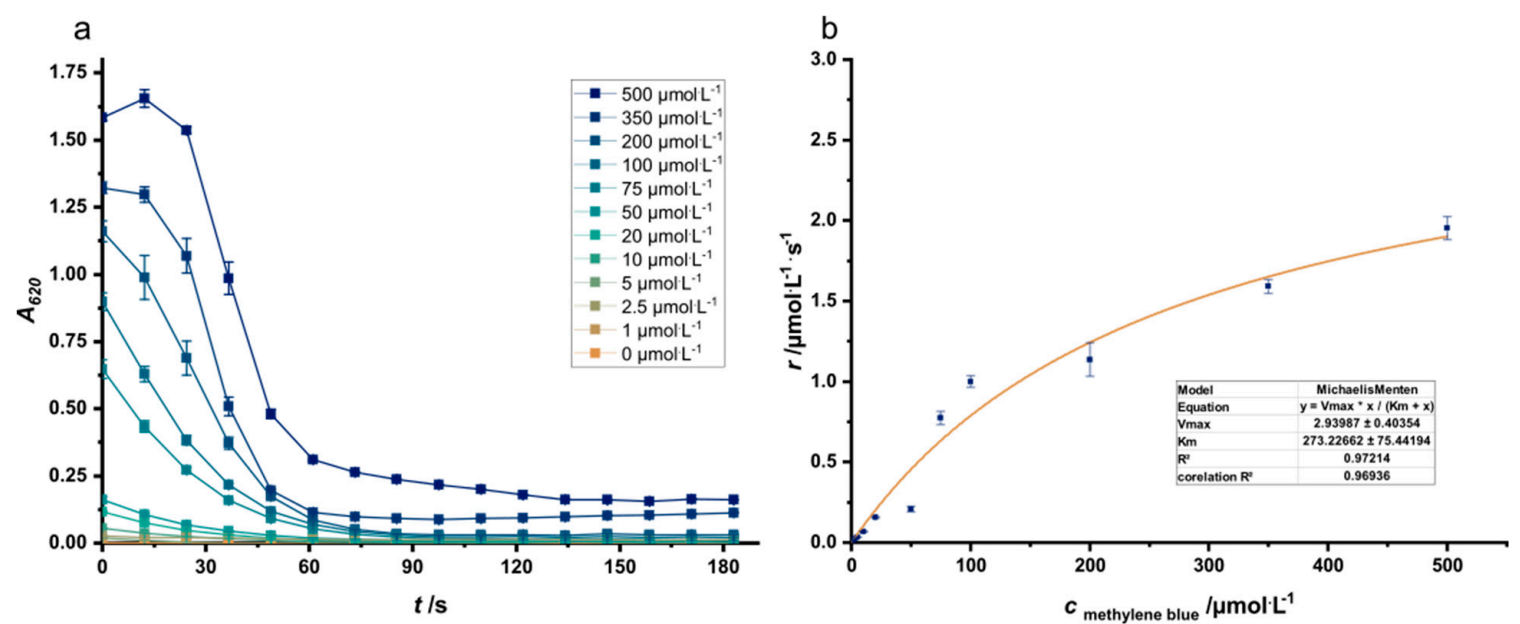

Figure 2. Reduction kinetics of methylene blue for Strain JG991 (a). Assays have been conducted in PBS minimal medium with an $\mathrm{OD}_{600}=6$. The highest reduction rates have been fitted to a Michaelis-Menten model (b).

\subsection{Analytical Methods}

The chemical analysis of the growth experiments and cell suspension assays was conducted via HPLC (Ultimate 3000 DAD and RI-Detector, Thermo Scientific, Waltham, MA, USA) with an Aminex HPX 87-H column (Bio-Rad, Hercules, CA, USA) at $60{ }^{\circ} \mathrm{C}$ with $5 \mathrm{mmol} / \mathrm{L} \mathrm{H}_{2} \mathrm{SO}_{4}$ as the mobile phase. Acetoin was also quantified using the Voges-Proskauer reaction as described by Förster et al. [22].

\subsection{Calculation of Evaluation Parameters}

The electro-fermentation experiments have been evaluated according to the average current density within the $8 \mathrm{~h}$ time frame of the experiment (j), coulombic efficiency (CE), yield (Y), and productivity (Q). The parameters have been calculated following these formulas:

$$
\mathrm{j}=\frac{\int_{t_{0}}^{t_{8}} I}{t_{8}} \quad \mathrm{CE}=\frac{\int_{t_{0}}^{t_{8}} I}{c^{\cdot} V_{r} \cdot z_{e} \cdot \epsilon \cdot N_{A}} \quad \mathrm{Y}=\frac{c_{\text {Ace }}}{c_{\text {Gluc }}} \quad \mathrm{Q}=\frac{c_{\text {Ace }} \cdot M_{\text {Ace }}}{t}
$$


$I$ : electrical current, $A$ : electrode surface, $\mathrm{t}$ : time, $V_{r}$ : reactor volume, $z_{e}$ : electrons per reaction, $c$ : concentration, $\epsilon$ : elementary charge, M: Molar Mass, Ace: Acetoin, Gluc: Glucose, $N_{A}$ : Avogadro constant.

\section{Results and Discussion}

In a previous study, we established the production of acetoin from glucose in an electrode-assisted fermentation [22]. The addition of methylene blue was necessary to allow electron transfer from the periplasm to the anode surface. While the carbon efficiency set a new benchmark, the space-time yield was rather low compared to oxic processes. Hence, the initial aim of this study was to elucidate the theoretically achievable conversion rate based solely on the kinetics of methylene blue reduction by the strain. Therefore, $K_{\mathrm{M}}$ and $V_{\max }$ of methylene blue reduction were determined in a microtiter-based reduction assay. The measured methylene blue reduction rate for the $K_{\mathrm{M}}$ value of $273 \mu \mathrm{mol} / \mathrm{L}$ was $1.4 \mu \mathrm{mol} / \mathrm{L} / \mathrm{s}$. In comparison, the rate for $50 \mu \mathrm{mol} / \mathrm{L}$ was $0.45 \mu \mathrm{mol} / \mathrm{L} / \mathrm{s}$ (Figure 2). This value is equivalent to a theoretical current density of $498.35 \mathrm{~mA} / \mathrm{m}^{2}$ under conditions applied in the experiment of Förster et al. [22]. In said experiment, however, only $115.8 \pm 6.7 \mathrm{~mA} / \mathrm{m}^{2}$ were measured. Hence, if the reduction rate of the production strain in an electro-fermentation setup could converge to the rates of this idealized reduction assay, an increase in the metabolic activity of up to 4.3-fold could be achieved. For a methylene blue concentration of $273 \mu \mathrm{mol} / \mathrm{L}$ which equals the $K_{\mathrm{M}}$ value of the cellular system an increase of up to 13.9-fold might be possible. Still, this theoretical transformation of methylene blue reduction kinetics into current densities does not account for a loss of mediator over time in the BES (bioelectrochemical system), it also neglects possible mass transport limitations with regards to substrate uptake. Moreover, the rather fast initial methylene blue reduction kinetics will be hampered by the growth inhibiting effect of this electron shuttle that can also pass the inner membrane [26,27]. Still, the comparison of the data achieved from electro-fermentation experiments with these theoretical values reveals to which account the mentioned factors indeed limit the overall process and give a clear maximum for the achievable current density with the initial strain's physiology.

\subsection{Adaptation to Improved Anoxic Respiration}

Previous experiments revealed that the deletion of all fermentation pathways in the developed production strain led to a severe limitation of growth also under anoxic respiratory conditions. The physiological reason for this remained at least partly enigmatic. The deletion of $a c k / p t a$ will lead to a reduced production of ATP that will influence the growth rate and yield. Interestingly, when strains with an increasing number of deletions in fermentation pathways were compared, it was observed that the growth rate was already decreased to $17 \%$ of the initial level after the first two deletions steps ( $f r d$ and $a d h$ gene). Further, the deletion of $l d h$ lowered the growth rate to $8 \%$ of the initial level and the loss of $a c k / p t a$ to $5 \%$. In contrast, the deletions of $f r d$, adh, and ldh combined reduced the biomass yield to $50 \%$ of the initial level, while the additional deletion of the pta/ack locus led to $15 \%$ of the initial value [22]. Albeit, the growth and yield data suggest that the deletion of NADH reoxidation pathways seems to have a general dysfunctional central metabolism as consequence. Hence, we aimed for an adaptation experiment and hypothesized that consecutive transfers on the anoxic medium would select for mutations that lead to a more balanced central metabolism and consequently faster growth.

The medium for the selection experiment was altered compared to our previous study since growth experiments revealed that the addition of yeast extract instead of casamino acids can increase anoxic growth by the strain (Appendix A Figure A1). Moreover, we aimed for optimizing the medium concerning the later application in a bioelectrochemical system. Hence, we determined the effect of either phosphate-, HEPES- or MOPS-buffer on the electrochemical interaction of methylene blue with the electrode using cyclovoltammetry. The experiments revealed that the highest current could be observed using MOPS-buffer, while the application of HEPES and phosphate-buffer led to $25 \%$ and $12 \%$ reduced peak currents (Appendix A Figure A2a). Moreover, the addition of yeast extract to the 
medium did not influence the methylene blue redox reaction in the conducted cyclovoltammetry experiments (Appendix A Figure A2b).

With this optimized medium, we started the selection experiment using DMSO as the electron acceptor and glucose as the electron donor. DMSO was chosen as its reduction is dependent on menaquinol which is also the electron donor for the heterologously produced CymA from S. oneidensis. Production of the latter is key for the introduced synthetic electron transport chain to methylene blue. After 16 transfers, the growth rate increased 3-fold from $0.016 \pm 0.003$ for the progenitor strain JG991 to $0.050 \pm 0.001$ for the developed strain, which will be referred to as JG1295 (Figure 3a,b). Of note, we continued the experiment for 7 further transfers but could not observe an increase in growth past transfer 16. It is further notable, that the lag phase has been reduced from approximately $100 \mathrm{~h}$ (JG991) to less than $24 \mathrm{~h}$ (JG1295). Still, an E. coli control strain that is not fermentation deficient shows no apparent lag phase and grows twice as fast as JG1295. Overall, the conducted adaptation reduced the gap in growth rate between control and adapted strain from 6-fold to 2-fold. Of note, the observed effect is specific for anaerobic growth since a control experiment under oxic conditions did not reveal a statistically significant difference between the growth rates of strain JG991 and JG1295 (Figure 4).
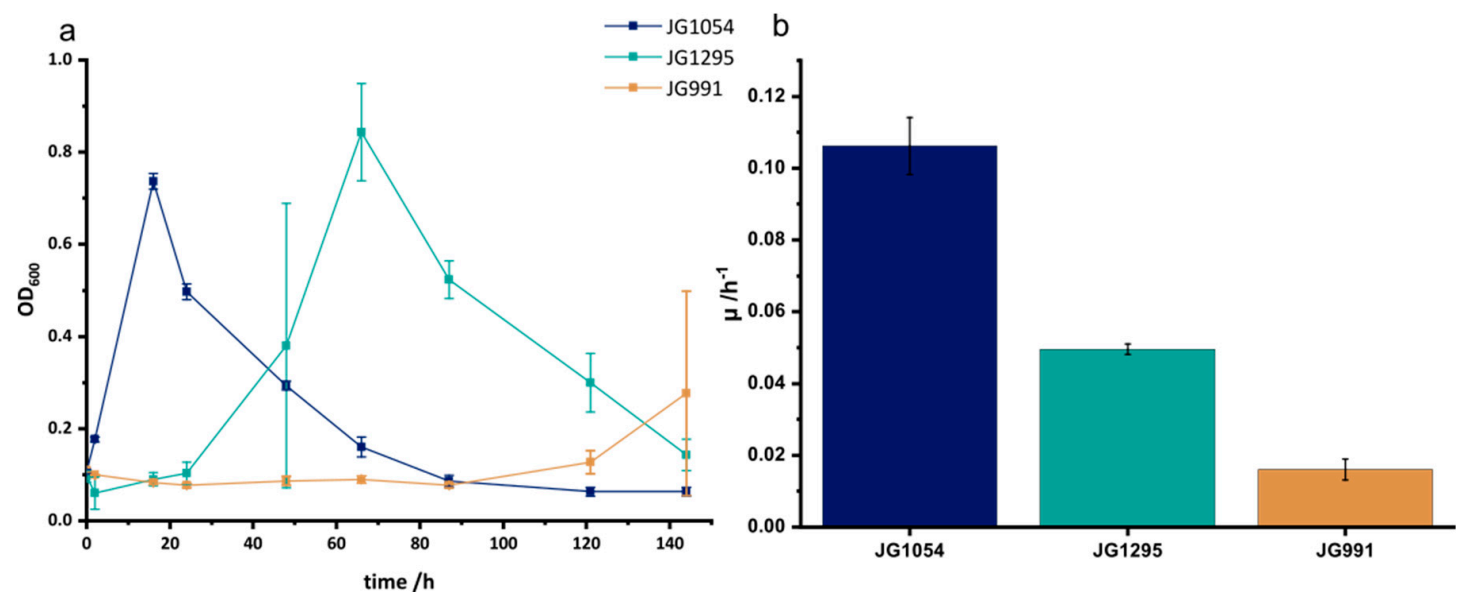

Figure 3. Anaerobic growth in MOPS buffered medium supplemented with $40 \mathrm{mmol} / \mathrm{L} \mathrm{DMSO}$, $20 \mathrm{mmol} / \mathrm{L}$ glucose, and $0.1 \%$ yeast extract. (a) Growth curve for the previous production strain (JG991) and the newly adapted strain (JG1295) in comparison to a reference strain without modifications in the mixed acid fermentation pathway (JG1054). The growth rates for this experiment are represented in (b).
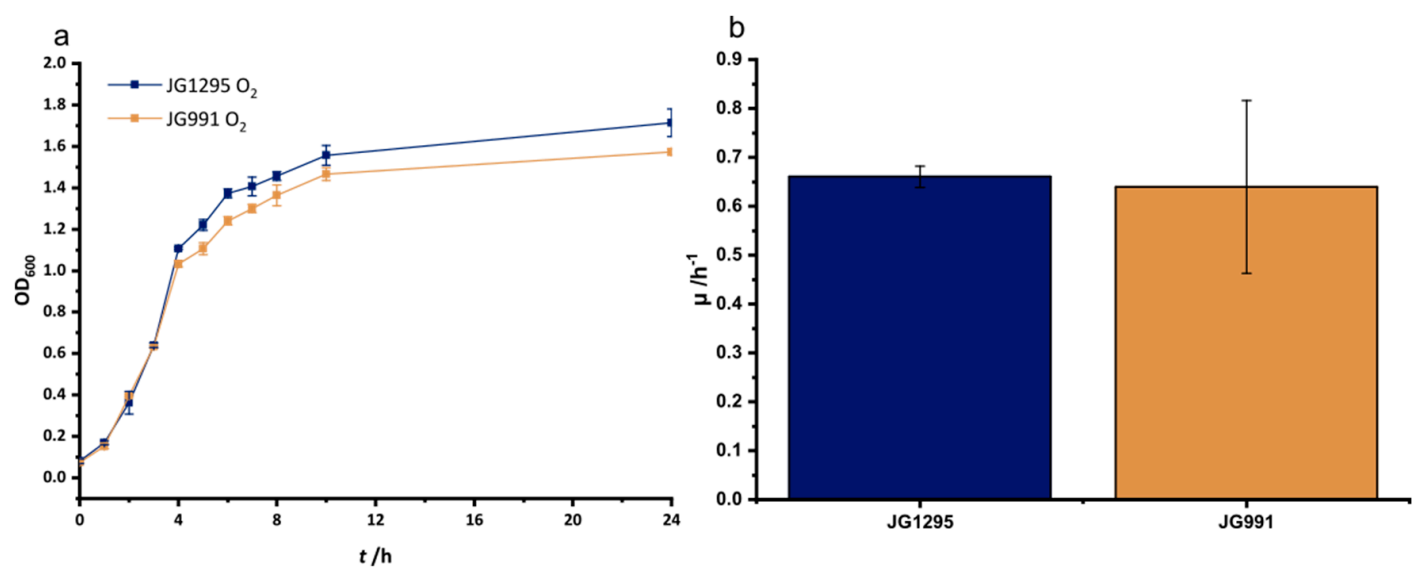

Figure 4. Aerobic growth in MOPS- Medium supplemented with $20 \mathrm{mmol} / \mathrm{L}$ glucose and $0.1 \%$ yeast extract. (a) Displayed are growth curves for the previous production strain (JG991) and the newly adapted strain (JG1295). The growth rates for this experiment are represented in (b). 


\subsection{The Adaptation to Growth on DMSO Is Based on Three Point Mutations}

We resequenced the genome of the strain to correlate the phenotype of the organism to specific changes in the genome sequence. The analysis revealed three variants with frequencies above $90 \%$ and a coverage of at least 20× (Table 4). Two mutations were found in genes encoding enzymes of the central metabolism. A stop codon was introduced in the gene for the pyruvate-formate-lyase ( pfl) by replacing amino acid (AA) 431 (glutamate). A second point mutation in the gene of the dihydrolipoamide acetyltransferase subunit $(a c e F)$ of the pyruvate dehydrogenase replaces aspartate 430 by glycine. Moreover, the gene for the RNA polymerase rpoC was modified by replacing proline 359 by leucine (AA359).

Table 4. Variant analysis of JG1295 compared to JG991. Represented are variants with a frequency of above $90 \%$ and a coverage of $20 \times$.

\begin{tabular}{cccccc}
\hline Base & Gene & Type & Mutation & Effect & Fidelity \\
\hline 4320496 & $p f l B$ & SNV & $\mathrm{G} \rightarrow \mathrm{A}$ & Gln to Stop (AA431) & $112 / 112(100 \%)$ \\
3009449 & $r p o C$ & SNV & $\mathrm{T} \rightarrow \mathrm{C}$ & Pro to Leu (AA359) & $155 / 156(99.4 \%)$ \\
3593620 & aceF & SNV & $\mathrm{A} \rightarrow \mathrm{G}$ & Asp to Gly (AA430) & $136 / 138(98.6 \%)$ \\
\hline
\end{tabular}

As the mutation in $p f l B$ leads to an interruption of the translation after approximately half the gene, we have to assume that pyruvate will not be converted to acetyl-CoA and formate via this enzyme anymore. Hence, it is interesting to observe that a second mutation occurred in an enzyme that can also catalyze the conversion of pyruvate to acetyl-CoA. The point mutation in aceF cannot lead to an inactive enzyme as this would cause no or at least very slow growth under oxic conditions, which could not be observed in this study (Figure 4) [28]. The aceF gene encodes subunit E2 of the pyruvate dehydrogenase to which E1 and E3 bind non-covalently. E2 consists of three lipoyl-domains at the N-terminus, a peripheral subunit-binding domain, and a large C-terminal core-forming acetyl-transferase domain to which the here observed mutation is localized [29,30]. Although the pyruvate-formate-lyase is the major pyruvate converting enzyme under anoxic conditions, the expression levels of the pyruvate dehydrogenase do not seem to be negatively influenced by the absence of oxygen [31]. Still, the activity of the enzyme is regulated by the NADH sensitivity of the dihydrolipoamide acetyltransferase subunit and the prevailing higher NADH/NAD ratios under anoxic conditions [22-34]. In fact, screening for mutants with higher ethanol productivity revealed clones with point mutations in the aceF gene, which rendered the enzyme insensitive to NADH-inhibition. Still, these mutations (H322Y or E354K) occurred at different positions [31]. Nevertheless, the situation is different in the here studied strain and a selection for an NADH-insensitive enzyme is unlikely. The genes for the majority of enzymes that would consume acetyl-CoA in the wild type under anoxic conditions were deleted. As the citric acid cycle is also downregulated, it would be detrimental for the strain to produce higher concentrations of acetyl-CoA, as accumulating CoA-esters can be toxic to the cell [35]. Moreover, we know that the carbon yield under acetoin-producing conditions is not lower (see below) compared to the strain before ALE which suggests that the available pyruvate pool is at least stable. Additionally, the mutation in the aceF-gene does not lead to a growth disadvantage under oxic conditions, which would indicate a generally reduced enzymatic activity. Hence, we hypothesize that the mutations render the enzyme even more stringent regarding reduced activity under the cellular conditions during anoxic growth. The NADH to NAD ratio as well as the cellular pyruvate concentrations could be used as triggers to reduce the enzyme's activity. The TCA cycle could still be delivered by necessary intermediates via the reduced acetyl-CoA pool and-probably more important-via the routes from pyruvate or phosphoenolpyruvate to oxaloacetate [36]. These three delivery routes will most likely be sufficient to support building block formation for biomass production under DMSO reducing conditions. Following this line of thought, the observed truncation and most probable deactivation of the pyruvate formate lyase would be a selective advantage as it simply stops the major acetyl-CoA producing reaction under anoxic conditions. The high pyruvate flux establishes in wild type E. coli an acetyl-CoA pool that is 
mainly deployed for energy production and redox balancing reactions [37,38]. As the mutant cannot catalyze these reactions anymore the high flux will not be relevant to sustain growth and-as described above-detrimental due to CoA-ester accumulation. While it is from a physiological viewpoint straight forward to hypothesize on the function of the $p f l$ and aceF mutations it sems impossible to easily explain the potential impact of the $r p o C$ mutation. RNA polymerase genes are often found to be targets for mutation in a multitude of screens and it is not always obvious how the particular mutation leads to the observed change in phenotype [39]. Nevertheless, we are not aware of a screen that would have revealed particularly this mutation before [40]. Overall, it is difficult to assess the influence of the individual point mutations as the two mutations in pyruvate converting enzymes will likely be interdependent regarding the growth stimulating effect. Moreover, it is not possible to easily assess the function of the rpoC mutation. The original strain grows poorly under anoxic respiratory conditions and partly forms flocks during growth. Hence, the mass limitations due to limited diffusion into the flocks will likely lead to an inhomogeneous transcriptome, which hampers comparison to the transcriptome of the strain after ALE.

\subsection{The Selected Mutations Increase Productivity and Current Production in Bioelectrochemical Systems}

Next, we sought to transfer the experiments from the cell suspension assays to bioelectrochemical systems. Strain JG1295 was introduced into the systems with an initial $\mathrm{OD}_{600}=6$. The chronoamperometric measurement of the electro-fermentation at $\mathrm{OD}_{600}=6$ revealed an initial current density maximum of $667.7 \pm 83.6 \mathrm{~mA} / \mathrm{m}^{2}$ after $4 \mathrm{~min}$ followed by a slow decrease in current density (Figure 5). Overall, the process and strain optimization conducted in this study led to a 3.6-fold increase in productivity compared to the previous report by Förster et al. [22]. The coulombic efficiency remained with $88.1 \pm 16.3 \%$ in the range on the previously observed high value of $84.4 \pm 4.1 \%$.

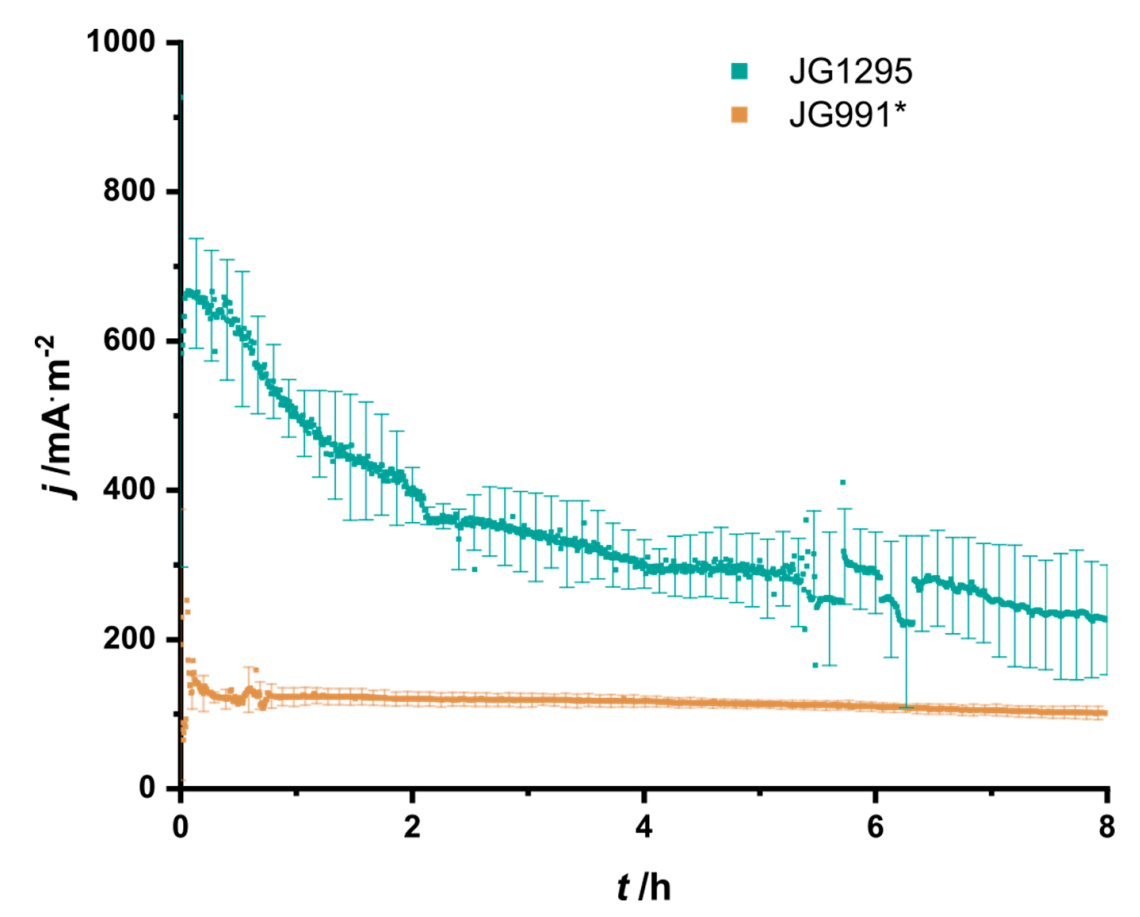

Figure 5. Chronoamperometric detection. Electro-fermentation in MOPS buffered medium supplemented with $10 \mathrm{mmol} / \mathrm{L}$ glucose and $0.1 \%$ yeast extract. Displayed is the current density over time for the previous production strain (JG991, yellow) and the newly adapted strain (JG1295, teal). * data originally published in [22] and added here as a reference for the performance of the newly adapted strain.

The increase in current density agrees well with the observed acceleration in the growth rate on DMSO. Hence, it seems as if central metabolism and not the electron transfer kinetics limit the process 
since the conducted methylene blue reduction assays suggest that higher current densities could be achieved considering the maximum reduction rates obtained in cell suspension assays. To confirm that the limitation of the strain is most probably in central metabolism and not in electron transfer kinetics, we increased the expression rate of $c y m A$ and stc by introducing an additional plasmid-encoded copy of the two genes (strain JG1397). The plasmid also contained the alsSD genes for acetoin production. The introduction of the plasmid and expression of the genes increased the methylene blue reduction rate by 2.45 -fold (Appendix A Figure A3). The experiments are consistent with previous results that reveal that cymA expression levels are constraining for extracellular electron transfer in E. coli and that the expression strength of genes encoding for cytochromes can have a crucial impact on electron transfer rates $[41,42]$. Still, the introduction of this strain to bioelectrochemical systems led to an insignificant increase in current density and acetoin yield compared to the progenitor strain JG1295 (Figure 6). This result bolsters the hypothesis that current density is limited by central metabolism rather than electron transfer kinetics.
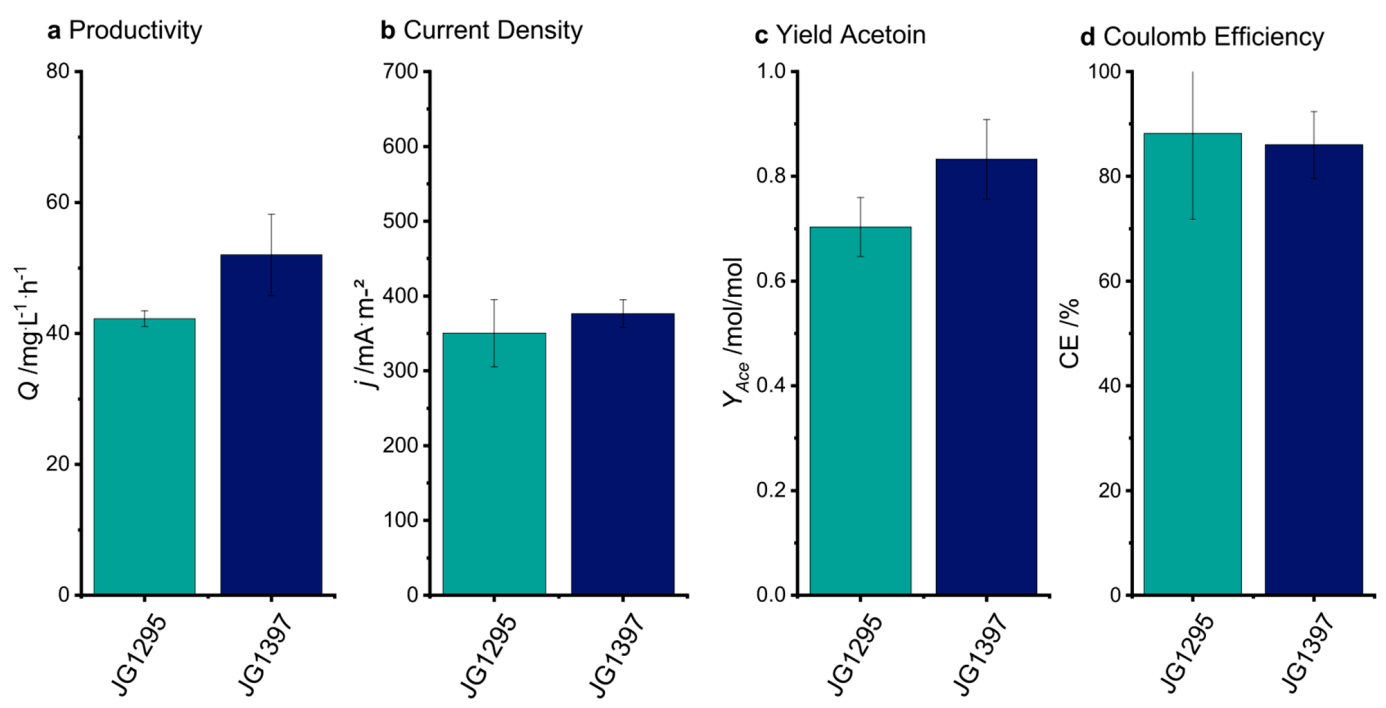

Figure 6. Evaluation of the electro-fermentation experiments for JG1295 and JG1397. All parameters are insignificant between the two strains. (a) Productivity (Q), (b) Average Current Density (j), (c) Yield Acetoin $\left(\mathrm{Y}_{\text {Ace }}\right)$, (d) Coulomb Efficiency (CE).

\section{Conclusions}

Using a targeted and non-targeted evolution of a production strain for anode-assisted acetoin production from glucose, it was possible to raise the current density (3.6-fold) and consequently the productivity (3.6-fold) that can be achieved with this strain.

This study started with establishing the characteristics of methylene blue reduction kinetics and a $K_{\mathrm{M}}$ value of $273 \mu \mathrm{mol} / \mathrm{L}$ was established for the whole-cell biocatalyst. Using this data and converting the measured reduction rates to a potentially achievable current density leads to a value of approximately $1.55 \mathrm{~A} / \mathrm{m}^{2}$. While the initial current densities observed in the electro-fermentation experiment are only 2.3-fold lower as this value, the average current density throughout $8 \mathrm{~h}$ is 4.8 -fold lower. This has the following implications: First, the development of the strain was successful as it is easily imaginable that the initially discussed mass transfer limitations of the BES cause the 2.3-fold difference in electron transfer rate. Second, this difference becomes more pronounced over longer periods is most probably due to the growth-inhibiting effect of methylene blue that is not interfering with the fast kinetics measured in cell suspension experiments. Hence, a further step towards a more stable current production would be to establish an E. coli strain that is more resilient towards higher methylene blue concentrations. Previous studies already revealed potential targets for a directed strain evolution approach. Apparently, the efflux pump AcrAB is necessary for E. coli to thrive in 
medium with higher methylene blue concentrations [43,44]. A defect in this efflux pump led to lacking growth already with $30 \mu \mathrm{mol} / \mathrm{L}$ methylene blue. The gene cluster is negatively regulated by AcrR. Nevertheless, our initial attempts to delete this repressor were so far not successful possibly due to a toxic effect of this mutation.

Increasing space-time yields of electrode-assisted fermentations will be key for their future biotechnological implementation. The here conducted study provides a workflow for strain development and characterization of the capabilities of the applied BES. Further research will focus on accelerating glucose metabolism in the strain and aim at increasing the amount of active biocatalyst within the bioreactors by advancing reactor technology.

Author Contributions: Conceptualization, J.G.; methodology, S.B., L.-A.P., J.G.; validation, S.B., L.-A.P., J.G.; formal analysis, S.B.; investigation, S.B., L.-A.P.; resources, J.G.; data curation, S.B.; writing-original draft preparation, J.G.; writing-review and editing, S.B., L.-A.P., J.G.; visualization, S.B.; supervision, J.G.; project administration, J.G.; funding acquisition, J.G. All authors have read and agreed to the published version of the manuscript.

Funding: We are grateful for the financial support from the German Ministry of Education and Research (BMBF) under the Program 03SF0496B. We also thank the State of Baden-Wuerttemberg for a direct scholarship to Laura-Alina Philipp.

Acknowledgments: We thank Falk Harnisch and Luis Filipe Morgado Rosa for the helpful discussion of the media composition. The authors thank Francesca Simonte for providing a codon-optimized sequence of $c y m A$ and stc.

Conflicts of Interest: The authors declare no conflict of interest.

\section{Appendix A}
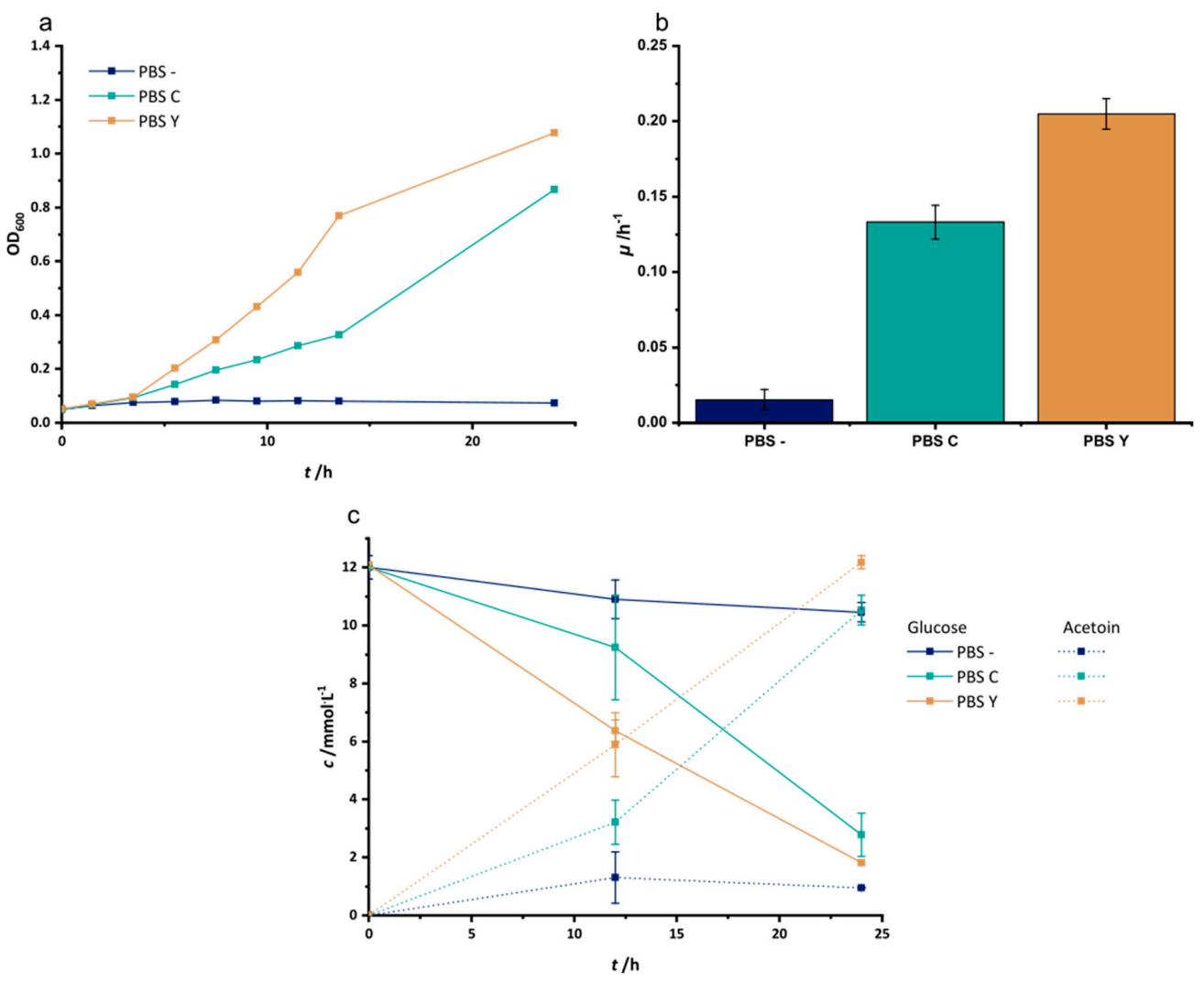

Figure A1. Influence of media supplementation on the metabolic rate of JG991. (a) shows the anaerobic growth of JG991 in PBS minimal medium with $40 \mathrm{mmol} / \mathrm{L} \mathrm{NO}_{3}{ }^{-}$and $12 \mathrm{mmol} / \mathrm{L}$ Glucose supplemented with $0.1 \%$ casein hydrolysate (PBS C) or $0.1 \%$ yeast extract (PBS Y). PBS—is without supplementation. The growth rates are represented in $(\mathbf{b})$. The analysis of substrate consumption and product formation is represented in (c). 


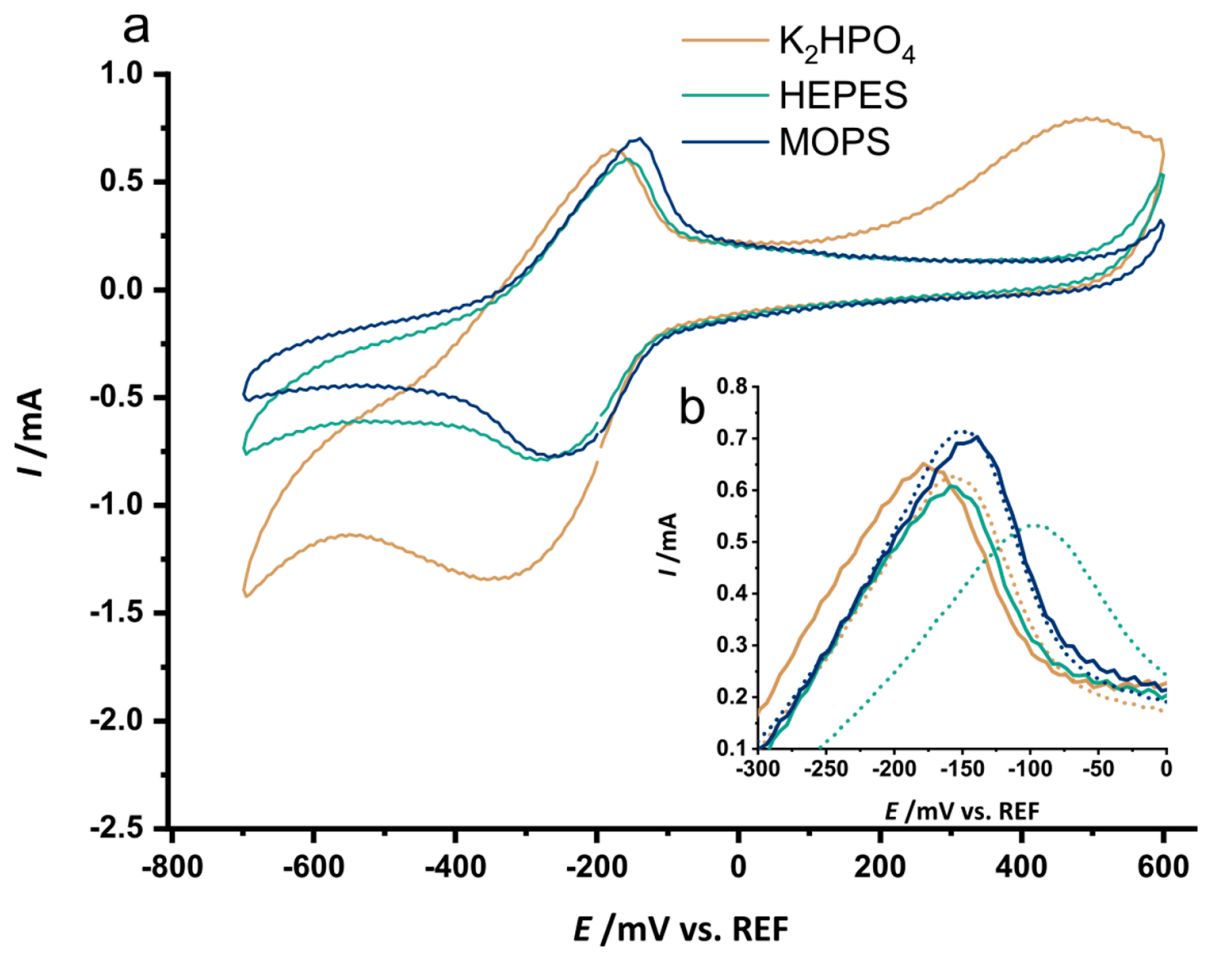

Figure A2. (a) Cyclic-Voltammetry of $50 \mu \mathrm{mol} / \mathrm{L}$ methylene blue in different buffer components as base for the electro-fermentation medium at a scan rate of $20 \mathrm{mV} / \mathrm{s}$. yellow- $\mathrm{K}_{2} \mathrm{HPO}_{4}$, teal- $\mathrm{HEPES}$, blue-MOPS, each $15 \mathrm{mmol} / \mathrm{L}$. (b) Peak currents for the methylene blue oxidation in differently buffered media compositions from A (compact lines) and fully complemented media compositions including $20 \mathrm{mmol} / \mathrm{L}$ Glucose and $1 \mathrm{~g} / \mathrm{L}$ yeast extract (dotted lines).

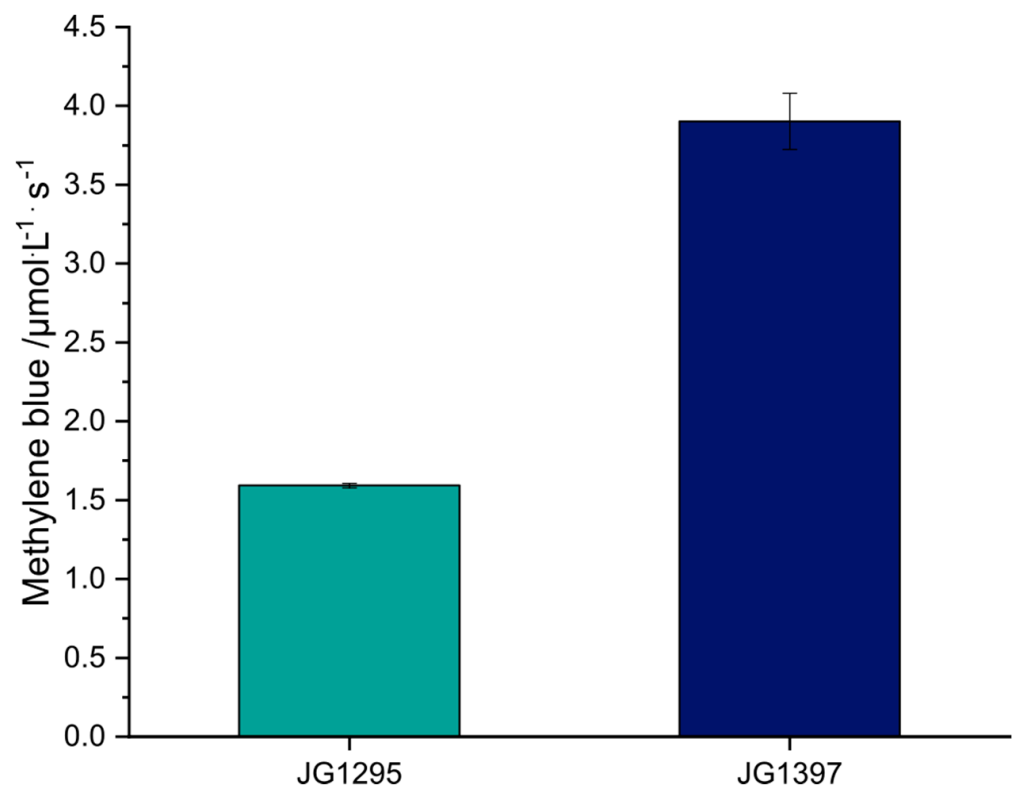

Figure A3. Reduction rates with $273 \mu \mathrm{mol} / \mathrm{L}$ methylene blue for JG1295 and JG1397 in a cell suspension of $\mathrm{OD}_{600}=6$.

Sequence A4: Codon-optimized sequence of $\operatorname{cymA}$. 
GCACGGTGGAGGCAAAGCAGGTGTTACCGTTCAGTGCCAGGACTGCCACCTGCCGCACGGTC CGGTTGACTACCTGATCAAGAAAATCATTGTTAGTAAAGACCTGTACGGTTTCCTGACCATCGA CGGTTTCAACACCCAGGCCTGGCTGGACGAAAACCGTAAAGAACAGGCAGACAAAGCGCTG GCATACTTCCGTGGTAACGACTCAGCTAACTGCCAGCACTGCCACACCCGTATCTACGAAAAC CAGCCGGAAACCATGAAACCGATGGCTGTTCGTATGCACACCAATAACTTCAAAAAAGACCC GGAAACCCGTAAAACCTGCGTTGACTGCCACAAAGGTGTTGCGCACCCGTACCCGAAAGG TTAA

Sequence A5: Codon optimized sequence of stc.

ATGAGCAAAAAACTGCTGTCAGTTCTGTTCGGTGCTTCTCTGGCAGCGCTGGCACTGTC TCCGACCGCATTTGCAGCGGACCAGAAACTGAGCGACTTCCACGCTGAATCAGGTGGCTGCGA ATCATGCCATAAAGACGGTACCCCGTCTGCAGACGGTGCCTTCGAATTCGCGCAGTGCCAGTCT TGCCACGGTAAACTGTCTGAAATGGACGCAGTTCACAAACCGCACGACGGTAACCTGGTTTGC GCTGACTGCCACGCTGTTCACGACATGAACGTTGGTCAGAAACCGACCTGCGAATCTTGCCAC GACGACGGTCGTACCAGCGCATCTGTTCTGAAAAAATAA

\section{References}

1. Causey, T.B.; Zhou, S.; Shanmugam, K.T.; Ingram, L.O. Engineering the metabolism of Escherichia coli W3110 for the conversion of sugar to redox-neutral and oxidized products: Homoacetate production. Proc. Natl. Acad. Sci. USA 2003, 100, 825-832. [CrossRef] [PubMed]

2. Jiang, Y.; May, H.D.; Lu, L.; Liang, P.; Huang, X.; Ren, Z.J. Carbon dioxide and organic waste valorization by microbial electrosynthesis and electro-fermentation. Water Res. 2019, 149, 42-55. [CrossRef] [PubMed]

3. Bhagchandanii, D.D.; Babu, R.P.; Sonawane, J.M.; Khanna, N.; Pandit, S.; Jadhav, D.A.; Khilari, S.; Prasad, R. A Comprehensive Understanding of Electro-Fermentation. Fermentation 2020, 6, 92. [CrossRef]

4. Philipp, L.-A.; Edel, M.; Johnston, C. Genetic engineering for enhanced productivity in bioelectrochemical systems. Adv. Virus Res. 2020, 111, 1-31. [CrossRef]

5. Korth, B.; Harnisch, F. Spotlight on the Energy Harvest of Electroactive Microorganisms: The Impact of the Applied Anode Potential. Front. Microbiol. 2019, 10, 1352. [CrossRef] [PubMed]

6. Hu, H.; Fan, Y.; Liu, H. Hydrogen production in single-chamber tubular microbial electrolysis cells using non-precious-metal catalysts. Int. J. Hydrogen Energy 2009, 34, 8535-8542. [CrossRef]

7. Cusick, R.D.; Bryan, B.; Parker, D.S.; Merrill, M.D.; Mehanna, M.; Kiely, P.D.; Liu, G.; Logan, B.E. Performance of a pilot-scale continuous flow microbial electrolysis cell fed winery wastewater. Appl. Microbiol. Biotechnol. 2011, 89, 2053-2063. [CrossRef]

8. Edel, M.; Horn, H.; Johnston, C. Biofilm systems as tools in biotechnological production. Appl. Microbiol. Biotechnol. 2019, 103, 5095-5103. [CrossRef]

9. McMillan, D.G.G.; Marritt, S.J.; Butt, J.N.; Jeuken, L.J.C. Menaquinone-7 Is Specific Cofactor in Tetraheme Quinol Dehydrogenase CymA. J. Biol. Chem. 2012, 287, 14215-14225. [CrossRef]

10. Fonseca, B.M.; Paquete, C.M.; Neto, S.E.; Pacheco, I.; Soares, C.M.; Louro, R.O. Mind the gap: Cytochrome interactions reveal electron pathways across the periplasm of Shewanella oneidensis MR-1. Biochem. J. 2012, 449, 101-108. [CrossRef]

11. Sturm, G.; Richter, K.; Doetsch, A.; Heide, H.; Louro, R.O.; Johnston, C. A dynamic periplasmic electron transfer network enables respiratory flexibility beyond a thermodynamic regulatory regime. ISME J. 2015, 9, 1802-1811. [CrossRef] [PubMed]

12. Shi, L.; Chen, B.; Wang, Z.; Elias, D.A.; Mayer, M.U.; Gorby, Y.A.; Ni, S.; Lower, B.H.; Kennedy, D.W.; Wunschel, D.S.; et al. Isolation of a High-Affinity Functional Protein Complex between OmcA and MtrC: Two Outer Membrane Decaheme c-Type Cytochromes of Shewanella oneidensis MR-1. J. Bacteriol. 2006, 188, 4705-4714. [CrossRef] [PubMed]

13. Beblawy, S.; Bursac, T.; Paquete, C.; Louro, R.; Clarke, T.A.; Johnston, C. Extracellular reduction of solid electron acceptors by Shewanella oneidensis. Mol. Microbiol. 2018, 109, 571-583. [CrossRef]

14. Costa, N.L.; Clarke, T.A.; Philipp, L.-A.; Gescher, J.; Louro, R.O.; Paquete, C.M. Electron transfer process in microbial electrochemical technologies: The role of cell-surface exposed conductive proteins. Bioresour. Technol. 2018, 255, 308-317. [CrossRef] 
15. Yu, S.; Lai, B.; Plan, M.R.; Hodson, M.P.; Lestari, E.A.; Song, H.; Krömer, J.O. Improved performance of Pseudomonas putida in a bioelectrochemical system through overexpression of periplasmic glucose dehydrogenase. Biotechnol. Bioeng. 2018, 115, 145-155. [CrossRef]

16. Lai, B.; Yu, S.; Bernhardt, P.V.; Rabaey, K.; Virdis, B.; Krömer, J.O. Anoxic metabolism and biochemical production in Pseudomonas putida F1 driven by a bioelectrochemical system. Biotechnol. Biofuels 2016, 9, 1-13. [CrossRef]

17. Vassilev, I.; Gießelmann, G.; Schwechheimer, S.K.; Wittmann, C.; Virdis, B.; Krömer, J.O. Anodic electro-fermentation: Anaerobic production of L-Lysine by recombinant Corynebacterium glutamicum. Biotechnol. Bioeng. 2018, 115, 1499-1508. [CrossRef]

18. Gescher, J.S.; Cordova, C.D.; Spormann, A.M. Dissimilatory iron reduction in Escherichia coli: Identification of CymA of Shewanella oneidensis and NapC of E. coli as ferric reductases. Mol. Microbiol. 2008, 68, 706-719. [CrossRef]

19. Jensen, H.M.; Albers, A.E.; Malley, K.R.; Londer, Y.Y.; Cohen, B.E.; Helms, B.A.; Weigele, P.; Groves, J.T.; Ajo-Franklin, C.M. Engineering of a synthetic electron conduit in living cells. Proc. Natl. Acad. Sci. USA 2010, 107, 19213-19218. [CrossRef]

20. Sturm-Richter, K.; Golitsch, F.; Sturm, G.; Kipf, E.; Dittrich, A.; Beblawy, S.; Kerzenmacher, S.; Johnston, C. Unbalanced fermentation of glycerol in Escherichia coli via heterologous production of an electron transport chain and electrode interaction in microbial electrochemical cells. Bioresour. Technol. 2015, 186, 89-96. [CrossRef]

21. TerAvest, M.A.; Zajdel, T.J.; Ajo-Franklin, C.M. The Mtr Pathway of Shewanella oneidensis MR-1 Couples Substrate Utilization to Current Production in Escherichia coli. ChemElectroChem 2014, 1, 1874-1879. [CrossRef]

22. Förster, A.H.; Beblawy, S.; Golitsch, F.; Johnston, C. Electrode-assisted acetoin production in a metabolically engineered Escherichia coli strain. Biotechnol. Biofuels 2017, 10, 1-11. [CrossRef] [PubMed]

23. Gibson, D.G.; Young, L.; Chuang, R.-Y.; Venter, J.C.; Hutchison, C.A.; Smith, H.O. Enzymatic assembly of DNA molecules up to several hundred kilobases. Nat. Methods 2009, 6, 343-345. [CrossRef] [PubMed]

24. Lutz, R. Independent and tight regulation of transcriptional units in Escherichia coli via the LacR/O, the TetR/O and AraC/I1-I2 regulatory elements. Nucleic Acids Res. 1997, 25, 1203-1210. [CrossRef] [PubMed]

25. Arslan, E.; Schulz, H.; Zufferey, R.; Künzler, P.; Thöny-Meyer, L. Overproduction of the Bradyrhizobium japonicum c-Type Cytochrome Subunits of thecbb3Oxidase in Escherichia coli. Biochem. Biophys. Res. Commun. 1998, 251, 744-747. [CrossRef]

26. Tuite, E.M.; Kelly, J.M. New trends in photobiology. Photochemical Interactions of Methylene Blue and Analogues with DNA and Other Biological Substrates. J. Photochem. Photobiol. B Biol. 1993, 21, 103-124. [CrossRef]

27. Usacheva, M.N.; Ba, M.C.T.; Biel, M.A. Comparison of the methylene blue and toluidine blue photobactericidal efficacy against gram-positive and gram-negative microorganisms. Lasers Surg. Med. 2001, 29, 165-173. [CrossRef]

28. Kim, Y.; Ingram, L.O.; Shanmugam, K.T. Construction of an Escherichia coli K-12 Mutant for Homoethanologenic Fermentation of Glucose or Xylose without Foreign Genes. Appl. Environ. Microbiol. 2007, 73, 1766-1771. [CrossRef]

29. Bleile, D.M.; Munk, P.; Oliver, R.M.; Reed, L.J. Subunit structure of dihydrolipoyl transacetylase component of pyruvate dehydrogenase complex from Escherichia coli. Proc. Natl. Acad. Sci. USA 1979, 76, 4385-4389. [CrossRef]

30. Stephens, P.E.; Darlison, M.G.; Lewis, H.M.; Guest, J.R. The Pyruvate Dehydrogenase Complex of Escherichia coli K12. Nucleotide Sequence Encoding the Dihydrolipoamide Acetyltransferase Component. JBIC J. Biol. Inorg. Chem. 1983, 133, 481-489. [CrossRef]

31. Kim, Y.; Ingram, L.O.; Shanmugam, K.T. Dihydrolipoamide Dehydrogenase Mutation Alters the NADH Sensitivity of Pyruvate Dehydrogenase Complex of Escherichia coli K-12. J. Bacteriol. 2008, 190, 3851-3858. [CrossRef] [PubMed]

32. Hansen, R.; Henning, U. Regulation of pyruvate dehydrogenase activity in Escherichia coli K12. Biochim. Biophys. Acta (BBA) Enzym. Biol. Oxid. 1966, 122, 355-358. [CrossRef]

33. Schmincke-Ott, E.; Bisswanger, H. Dihydrolipoamide Dehydrogenase Component of the Pyruvate Dehydrogenase Complex from Escherichia coli K12. Comparative Characterization of the Free and the Complex-Bound Component. JBIC J. Biol. Inorg. Chem. 1981, 114, 413-420. [CrossRef] [PubMed] 
34. Shen, L.C.; Atkinson, D.E. Regulation of pyruvate dehydrogenase from Escherichia coli. Interactions of adenylate energy charge and other regulatory parameters. J. Biol. Chem. 1970, 245, 5974-5978. [PubMed]

35. Brass, E.P. Overview of coenzyme A metabolism and its role in cellular toxicity. Chem. Interact. 1994, 90, 203-214. [CrossRef]

36. Gokarn, R.R.; Eiteman, M.A.; Altman, E. Metabolic Analysis of Escherichia coli in the Presence and Absence of the Carboxylating Enzymes Phosphoenolpyruvate Carboxylase and Pyruvate Carboxylase. Appl. Environ. Microbiol. 2000, 66, 1844-1850. [CrossRef]

37. Sawers, R. The aerobic/anaerobic interface. Curr. Opin. Microbiol. 1999, 2, 181-187. [CrossRef]

38. Sawers, G.; Böck, A. Anaerobic regulation of pyruvate formate-lyase from Escherichia coli K-12. J. Bacteriol. 1988, 170, 5330-5336. [CrossRef]

39. Murphy, H.; Cashel, M. Isolation of RNA Polymerase Suppressors of a (p)ppGpp Deficiency. Methods Enzym. 2003, 371, 596-601. [CrossRef]

40. Klein-Marcuschamer, D.; Santos, C.N.S.; Yu, H.; Stephanopoulos, G. Mutagenesis of the Bacterial RNA Polymerase Alpha Subunit for Improvement of Complex Phenotypes. Appl. Environ. Microbiol. 2009, 75, 2705-2711. [CrossRef]

41. Goldbeck, C.P.; Jensen, H.M.; TerAvest, M.A.; Beedle, N.; Appling, Y.; Hepler, M.; Cambray, G.; Mutalik, V.; Angenent, L.T.; Ajo-Franklin, C.M. Tuning Promoter Strengths for Improved Synthesis and Function of Electron Conduits in Escherichia coli. ACS Synth. Biol. 2013, 2, 150-159. [CrossRef] [PubMed]

42. Vellingiri, A.; Song, Y.E.; Munussami, G.; Kim, C.; Park, C.; Jeon, B.H.; Lee, S.-G.; Kim, J.R. Overexpression of $c$-type cytochrome, CymA in Shewanella oneidensis MR-1 for enhanced bioelectricity generation and cell growth in a microbial fuel cell. J. Chem. Technol. Biotechnol. 2019, 94, 2115-2122. [CrossRef]

43. Sugino, Y. Mutants of Escherichia coli sensitive to methylene blue and acridines. Genet. Res. 1966, 7, 1-11. [CrossRef] [PubMed]

44. Henson, J.M.; Walker, J.R. Genetic analysis of acrA and lir mutations of Escherichia coli. J. Bacteriol. 1982, 152, 1301-1302.

Publisher's Note: MDPI stays neutral with regard to jurisdictional claims in published maps and institutional affiliations.

(C) 2020 by the authors. Licensee MDPI, Basel, Switzerland. This article is an open access article distributed under the terms and conditions of the Creative Commons Attribution (CC BY) license (http://creativecommons.org/licenses/by/4.0/). 